\title{
Effects of sulfate on heavy metal release from iron corrosion scales in drinking water distribution system
}

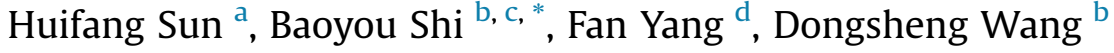 \\ a Institute of Resources and Environmental Engineering, Shanxi University, Taiyuan 030006, China \\ ${ }^{\mathrm{b}}$ Key Laboratory of Drinking Water Science and Technology, Research Center for Eco-Environmental Sciences, Chinese Academy of Sciences, Beijing 100085, \\ China \\ ${ }^{c}$ University of Chinese Academy of Sciences, Beijing 100049, China \\ d College of Engineering and Technology, Tianjin Agricultural University, Tianjin 300384, China
}

\section{A R T I C L E I N F O}

\section{Article history:}

Received 2 November 2016

Received in revised form

8 February 2017

Accepted 10 February 2017

Available online 13 February 2017

\section{Keywords:}

Drinking water distribution system

Heavy metal release

Iron corrosion scale

Sulfate

\begin{abstract}
A B S T R A C T
Trace heavy metals accumulated in iron corrosion scales within a drinking water distribution system (DWDS) could potentially be released to bulk water and consequently deteriorate the tap water quality. The objective of this study was to identify and evaluate the release of trace heavy metals in DWDS under changing source water conditions. Experimental pipe loops with different iron corrosion scales were set up to simulate the actual DWDS. The effects of sulfate levels on heavy metal release were systemically investigated. Heavy metal releases of $\mathrm{Mn}, \mathrm{Ni}, \mathrm{Cu}, \mathrm{Pb}, \mathrm{Cr}$ and As could be rapidly triggered by sulfate addition but the releases slowly decreased over time. Heavy metal release was more severe in pipes transporting groundwater (GW) than in pipes transporting surface water (SW). There were strong positive correlations $\left(\mathrm{R}^{2}>0.8\right)$ between the releases of $\mathrm{Fe}$ and $\mathrm{Mn}, \mathrm{Fe}$ and $\mathrm{Ni}, \mathrm{Fe}$ and $\mathrm{Cu}$, and Fe and $\mathrm{Pb}$. When switching to higher sulfate water, iron corrosion scales in all pipe loops tended to be more stable (especially in pipes transporting GW), with a larger proportion of stable constituents (mainly $\mathrm{Fe}_{3} \mathrm{O}_{4}$ ) and fewer unstable compounds ( $\beta-\mathrm{FeOOH}, \gamma-\mathrm{FeOOH}, \mathrm{FeCO}_{3}$ and amorphous iron oxides). The main functional iron reducing bacteria (IRB) communities were favorable for the formation of $\mathrm{Fe}_{3} \mathrm{O}_{4}$. The transformation of corrosion scales and the growth of sulfate reducing bacteria (SRB) accounted for the gradually reduced heavy metal release with time. The higher metal release in pipes transporting GW could be due to increased $\mathrm{Fe}_{6}(\mathrm{OH})_{12} \mathrm{CO}_{3}$ content under higher sulfate concentrations.
\end{abstract}

() 2017 Elsevier Ltd. All rights reserved.

\section{Introduction}

The accumulation of heavy metals within drinking water distribution systems (DWDS) has caused considerable concern. Even if heavy metals are present at concentrations below their maximum contaminant levels (MCLs) or at non-detectable levels in treated water, they can accumulate within deposits and corrosion scales that exist in DWDS (Peng et al., 2012; Lytle et al. 2004, 2010; Fisher et al., 2000; Lytle et al., 2004; Schock et al., 2008). Some iron compounds commonly found in corrosion scales, such as goethite $(\alpha-\mathrm{FeOOH})$, lepidocrocite $(\gamma-\mathrm{FeOOH})$, magnetite $\left(\mathrm{Fe}_{3} \mathrm{O}_{4}\right)$ and ferrihydrite have strong affinity to adsorb and concentrate trace heavy

\footnotetext{
* Corresponding author. Key Laboratory of Drinking Water Science and Technology, Research Center for Eco-Environmental Sciences, Chinese Academy of Sciences, Beijing 100085, China. Tel.: +86 1062924821.

E-mail address: byshi@rcees.ac.cn (B. Shi).
}

metals, such as arsenic (As), chromium ( $\mathrm{Cr}$ ), lead (Pb), vanadium (V) and uranium (U) (Peng et al., 2010; Sarin et al., 2001). Relative to iron compounds, manganese (Mn) oxides/oxyhydroxides are commonly found in DWDS, and these are highly effective at adsorbing metal ions, such as $\mathrm{Cr}$, copper ( $\mathrm{Cu}$ ), iron (Fe), nickel ( $\mathrm{Ni}$ ), $\mathrm{Pb}$ and strontium (Sr) ions (Gerke et al., 2016).

The primary concern with trace heavy metals in DWDS is the potential release of the metals back into the water (through particulate transport and/or chemical release, e.g. desorption, dissolution), which may result in elevated heavy metal levels in domestic tap water. For example, there was a major release of lead and other contaminants into a midsized Midwestern distribution system following the introduction of chlorination in the United States. Shortly after chlorination was instituted, numerous colored water complaints were received, and subsequent investigations found high levels of $\mathrm{Fe}, \mathrm{Cu}$ and $\mathrm{As}$ in the colored water specimens (Reiber and Dostal, 2000). Lytle et al. (2010) reported As 
concentration in domestic water was as high as $299 \mu \mathrm{g} \mathrm{L}^{-1}$, which was nearly six times the MCL of $50 \mu \mathrm{g} \mathrm{L}^{-1}$. Therefore, drinking water providers should be aware of the potential release of trace heavy metals that are pre-accumulated in iron corrosion scales, since these might pose a health risk if these contaminants are released into drinking water.

Alternative water sources and long distance water transport can help solve water shortage problems. However, source water switches can cause undesirable water quality changes due to the disturbance of corrosion scales by changes in water chemistry. Sulfate was identified as one of the most significant water quality parameters in many water chemical stability models and indices such as the Larson index (Larson and Skold, 1958). Under source switch condition, sulfate has been recognized as a causative agent of red water in many cases, and elevated levels of Fe or Mn in bulk water are associated with discolored water (Li et al., 2010; Ginige et al., 2011). For example, in a red water case caused by source water switch in a northern China city, it was found that the new water source had significantly higher sulfate concentration compared with local water source ( $200 \mathrm{mg} \mathrm{L}^{-1}$ vs $30 \mathrm{mg} \mathrm{L}^{-1}$ ) (Yang et al., 2014), but the effect of sulfate on the deterioration of water quality within DWDS are currently not fully understood.

Moreover, iron release from corrosion scales/deposits in DWDS is usually not considered to be a health concern but rather an aesthetic issue associated with discolored water. Fe and Mn based compounds commonly existing in DWDS corrosion scales are capable of adsorbing and concentrating trace heavy metals. We wonder if heavy metal release accompanied by iron release could result from switching to alternative source water and long distance transported water. The relationship and the interaction mechanisms between $\mathrm{Fe}$ and $\mathrm{Mn}$ release and heavy metal release are not well understood. The main factors influencing the release behavior of heavy metals are also not known.

This work sought to identify and evaluate the release of trace heavy metals under switching water quality conditions. Iron pipe sections from actual DWDS with different source water supply histories were collected for pipe loop set-up. The relationships of total iron release, trace heavy metal release and corrosion scale constituents under changing sulfate water conditions were systematically analyzed and discussed.

\section{Materials and methods}

\subsection{Pipe loop set-up and operation}

Test cast-iron pipes (approximately 20 years old) were obtained from two locations in a northern city of China, and labelled as PipeA and Pipe-B. Historically, Pipe-A was transporting finished surface water (SW1), and Pipe-B was transporting finished groundwater (GW1). Water sources, main finished water quality parameters and treatment processes of the corresponding water treatment plants are summarized in Table S1. Two pipe loop facilities were set up in parallel, and each facility consisted of five DN100 and 1-m-long test pipe sections and three 0.1-m-long coupon pipe sections (Fig. S1). The pipe loops with Pipe-A and Pipe-B were designated as Loop 1 (L1) and Loop 2 (L2), respectively.

A two-phase experiment was conducted for both pipe loops. Phase I: feed water was regular tap water collected from our lab without further disinfection (with low residual chlorine of $0.05-0.07 \mathrm{mg} \mathrm{L}^{-1}$ ). The sulfate concentration was about $75 \mathrm{mg} \mathrm{L}^{-1}$, and the duration was $50 \mathrm{~d}$ (equilibration period for stabilizing the concentration of total iron and turbidity of effluents). Phase II: sulfate concentration of feed water was increased by adding sodium sulfate to the regular tap water. Three sulfate concentrations were applied for each loop: for L1, 200, 250, and $300 \mathrm{mg} \mathrm{L}^{-1}$; for L2,
200, 230, and $250 \mathrm{mg} \mathrm{L}^{-1}$.

Experimental phases, operation conditions, and corresponding water types for each loop are listed in Table 1. We simulated the actual flow mode of water in the distribution system and the domestic use. A complete operation cycle was set at $48 \mathrm{~h}$, and routine operation cycle procedures were as follows: first, a certain amount of test water was prepared in a water tank; then water circulation was started and continued for $36 \mathrm{~h}$, corresponding to $16 \mathrm{~h}$ of hydraulic retention time (HRT) in cast-iron pipes; second, circulation was suspended and the water was kept motionless for $8 \mathrm{~h}$, then samples were taken for measurement; at the end, used water was discharged and preparations for a new cycle were started. The $8 \mathrm{~h}$ motionless time represented the night status when there was little or no water use. Water was circulated in test pipe loops using a centrifugal pump at a flow rate of $3.2 \mathrm{~m}^{3} \mathrm{~h}^{-1}$, and the flow velocity in test pipe sections was approximately $0.1 \mathrm{~m} \mathrm{~s}^{-1}$. The water temperature was maintained at $20 \pm 1^{\circ} \mathrm{C}$ using a heat-exchanging unit.

\subsection{Pipe section reactor set-up and operation}

Several small pipe section reactors (Loop 3) were assembled with cast iron pipes, which were harvested from another GW (GW2) service area in a northern city of China (Fig. S2). These pipes (denoted as Pipe-C) were approximately 20 years old, with diameter of DN100. Each test pipe was cut into 0.1-m-long experimental sections, and the cutting faces were coated with epoxy resin to prevent water contact. The HRT in pipe section reactors was $8 \mathrm{~h}$. A stirring device was installed in reactors to simulate water flow conditions in actual DWDS.

Raw tap water from the lab was fed into the pipe section reactors until the concentration of total iron and turbidity of effluents stabilized (phase I). Then the sulfate concentration was increased by adding sodium sulfate to the regular tap water at 200, 300, 400, $500,600 \mathrm{mg} \mathrm{L}^{-1}$ (phase II), to evaluate sulfate effects on the release of heavy metals from iron corrosion scales. The test used six concentration gradients (from 75 to $600 \mathrm{mg} \mathrm{L}^{-1}$ ), and was replicated five times (ran 1 ran 5).

\subsection{Analytical methods}

Water quality parameters, such as $\mathrm{pH}$, temperature, dissolved oxygen (DO), conductivity, turbidity, alkalinity, chloride $\left(\mathrm{Cl}^{-}\right)$and $\mathrm{SO}_{4}^{2-}$ were measured for both feed and effluent water. The $\mathrm{pH}$, temperature, DO and conductivity were measured using Portable Multiparameter meter (Sension156 $\mathrm{HACH}$, USA), and the turbidity was measured using a 2100P Turbidimeter (HACH, USA). Free chlorine was measured using a HACH DR2800 spectrophotometer. $\mathrm{SO}_{4}^{2-}$ and $\mathrm{Cl}^{-}$were analyzed using the Ion Chromatography System1000 (Dionex, USA). Fe, Mn, Cu, Zn, Pb, Ni, Cr and As were analyzed by Inductively Coupled Plasma Mass Spectrometer (ICP-MS, PerkinElmer Optima, 2000, USA). Unless otherwise specified, all chemicals used in this study were Analytical Reagent grade. Ultrapure nitric acid was used to digest samples for metal analysis.

\subsection{Characterization of iron corrosion scales}

Corrosion scale samples were collected from freshly obtained pipe sections and pipe loops L1 and L2 at the end of phase I and phase II, respectively. Typical corrosion scale samples with different appearances were classified and analyzed separately. Pretreatment procedures were as described previously (Yang et al., 2012). X-ray diffraction (XRD, D/max-rA, Rigaku Co., USA) and X-ray Fluorescence (XRF, Advant' XP, Thermo Electron, Switzerland) were performed to characterize the crystalline phase and elemental composition of corrosion scales. The instrumental information for 
Table 1

Pipe ID, water sources in each pipe loop, experimental conditions and feed water type.

\begin{tabular}{|c|c|c|c|c|c|c|}
\hline Pipe loop & Test pipe & Historic source water & Phases & Duration & Water type & Sulfate ( $\left.\mathrm{mg} \mathrm{L}^{-1}\right)$ \\
\hline Loop 1 & Pipe-A & SW1 & $\begin{array}{l}\text { I } \\
\text { II }\end{array}$ & $\begin{array}{l}1-50 \mathrm{~d} \\
52-86 \mathrm{~d} \\
88-122 \mathrm{~d} \\
124-174 \mathrm{~d}\end{array}$ & $\begin{array}{l}\text { Tap water } \\
\text { Simulated water }\end{array}$ & $\begin{array}{l}75 \\
200 \\
250 \\
300\end{array}$ \\
\hline Loop 2 & Pipe-B & GW1 & $\begin{array}{l}\text { I } \\
\text { II }\end{array}$ & $\begin{array}{l}1-50 \mathrm{~d} \\
52-86 \mathrm{~d} \\
88-122 \mathrm{~d} \\
124-174 \mathrm{~d}\end{array}$ & $\begin{array}{l}\text { Tap water } \\
\text { Simulated water }\end{array}$ & $\begin{array}{l}75 \\
200 \\
230 \\
250\end{array}$ \\
\hline Loop 3 & Pipe-C & GW2 & $\begin{array}{l}\text { I } \\
\text { II }\end{array}$ & $\begin{array}{l}7 \mathrm{~d} \\
25 \mathrm{~d}\end{array}$ & $\begin{array}{l}\text { Tap water } \\
\text { Simulated water }\end{array}$ & $\begin{array}{l}75 \\
200 \\
300 \\
400 \\
500 \\
600\end{array}$ \\
\hline
\end{tabular}

XRD and XRF as well as the quantification method for XRD were the same as described previously (Yang et al., 2012).

\section{Results and discussion}

\subsection{Structural and elemental composition of initial corrosion scales}

The morphology of corrosion scales on cast iron pipes differed depending on the type of historic source water (Fig. S3), which was described previously (Yang et al., 2012; Sun et al., 2014a). According to Yang et al. (2014), corrosion scales on pipes historically transporting treated SW (Pipe-A) with an appearance of a continuous thick layer (10-20 mm) could be divided into top surface and hard shell (THS), porous core layers (PCL), and entire tubercle (ET). THS and ET scales are at the interface between bulk water and the pipe wall, and were barriers that protected the pipe from further corrosion. Their stability changes have great impact on iron corrosion and metal release. Scales on pipes transporting GW (Pipe$B$ and Pipe-C) are relatively thin (only few millimeters or less than a millimeter) with non-tubercle-formed corrosion scale (TNCS). The hollow tubercle (HT), scale type which formed in the pipes transporting GW, was not detected in the present study.

A total of 22 inorganic elements (including $\mathrm{Fe}, \mathrm{Si}, \mathrm{Ca}, \mathrm{Al}, \mathrm{Na}, \mathrm{Mg}$, $\mathrm{S}, \mathrm{K}, \mathrm{Mn}, \mathrm{P}, \mathrm{Ti}, \mathrm{Zn}, \mathrm{Cl}, \mathrm{Mo}, \mathrm{Ni}, \mathrm{Cr}, \mathrm{V}, \mathrm{Sr}, \mathrm{Cu}, \mathrm{Pt}, \mathrm{Pb}$ and $\mathrm{As}$ ) in DWDS corrosion scales were detected in the corrosion scale samples. Table 2 summarizes the contents $\left(\mu \mathrm{g} \mathrm{g}^{-1}\right.$ ) of some main elements in the initial corrosion scales. Fe was the largest component in all of the scales analyzed, with mean content of $519640 \mu \mathrm{g} \mathrm{g}^{-1}$. The second most abundant element for the two scales of TNCS was Ca (mean $=22100 \mu \mathrm{g} \mathrm{g}^{-1}$ ), and nearly 6.5 times of the Ca content in THS, PCL and ET ( mean = $3424 \mu \mathrm{g} \mathrm{g}^{-1}$ ). As, $\mathrm{Cr}, \mathrm{Cu}, \mathrm{Mg}, \mathrm{Mn}, \mathrm{Pb}$ and $\mathrm{Zn}$ also had higher levels in TNCS, compared with other scale samples. The contents of S in the THS, PCL and ET scales were greater than those in the two scales of TNCS, and the highest content was present in the PCL scale. S occurrence in scales is likely to be in the form of troilite, a common under-layer component of iron corrosion scales (Benjamin et al., 1996). We did not detect crystalline $\mathrm{Fe}_{\mathrm{x}} \mathrm{S}_{\mathrm{y}}$ minerals by XRD, but the XRF results demonstrated that $S$ was common.

\subsection{Heavy metal release}

Inorganic contaminants in DWDS solids came from several sources, but mainly from source water and pipe materials. According to Peng et al. (2012), As, V and U released from mineral deposits dissolution were more prevalent in GW supplies, since they could not be efficiently removed by traditional water treatment plants. Some other metal ions such as $\mathrm{Pb}, \mathrm{Cu}, \mathrm{Cd}, \mathrm{Cr}$ and other impurities might originate from pipe materials and pipe joints in DWDS (Masters et al., 2016). We studied the effects of sulfate on seven heavy metals (including $\mathrm{As}, \mathrm{Cr}, \mathrm{Cu}, \mathrm{Mn}, \mathrm{Ni}, \mathrm{Pb}$ and $\mathrm{Zn}$ ) release using cast iron pipe-loops with different corrosion scales. The changes of heavy metal release under different sulfate concentrations are presented in Fig. 1. Releases of $\mathrm{As}, \mathrm{Cr}, \mathrm{Cu}, \mathrm{Mn}, \mathrm{Ni}$ and $\mathrm{Pb}$ increased immediately at higher sulfate concentration but the releases gradually decreased over time. Compared with L1, the

Table 2

Elemental composition of corrosion scales under different experimental conditions $(\mu \mathrm{g} / \mathrm{g})$

\begin{tabular}{|c|c|c|c|c|c|c|c|c|c|c|c|c|c|c|}
\hline Scale sample ID & Experimental phase & $\mathrm{Al}$ & As & $\mathrm{Ca}$ & $\mathrm{Cu}$ & $\mathrm{Cr}$ & $\mathrm{Fe}$ & $\mathrm{Mg}$ & Mn & $\mathrm{Ni}$ & $\mathrm{Pb}$ & $\mathrm{S}$ & $\mathrm{Si}$ & $\mathrm{Zn}$ \\
\hline L1 tap water-THS ${ }^{\text {a }}$ & Phase I & 2350 & 11 & 1870 & 22 & 26 & 535500 & 1470 & 912 & 114 & 20 & 5910 & 6680 & 207 \\
\hline L1 tap water-PCL ${ }^{b}$ & Phase I & 1870 & $\mathrm{NA}^{\mathrm{e}}$ & 473 & 48 & 40 & 562600 & 1140 & 406 & 65 & 31 & 15300 & 13700 & 68 \\
\hline L1 tap water-ET ${ }^{\mathrm{C}}$ & Phase I & 2410 & NA & 7930 & 50 & 35 & 522100 & 973 & 881 & 39 & NA & 7540 & 12900 & 193 \\
\hline L2 tap water-TNCS ${ }^{\mathrm{d}}$ & Phase I & 1950 & 47 & 22800 & 79 & 67 & 514000 & 3080 & 1220 & 82 & 69 & 1780 & 15900 & 533 \\
\hline L3 tap water-TNCS & Phase I & 10400 & NA & 21400 & 68 & 59 & 464000 & 3420 & 1200 & 85 & 58 & 2030 & 10300 & 362 \\
\hline L1 simulated water-THS & Phase II & 2610 & NA & 3910 & NA & NA & 531200 & 686 & 718 & NA & NA & 6530 & 9380 & 111 \\
\hline L1 simulated water-PCL & Phase II & 2380 & NA & 195 & NA & 18 & 570500 & 659 & 173 & NA & NA & 18100 & 11100 & 36 \\
\hline L1 simulated water-ET & Phase II & 2350 & NA & 8390 & 26 & 31 & 529000 & 604 & 623 & 27 & NA & 7640 & 11400 & 132 \\
\hline L2 simulated water-TNCS & Phase II & 4100 & NA & 20800 & 39 & NA & 526100 & 1420 & 777 & NA & 29 & 3970 & 19500 & 239 \\
\hline L3 simulated water-TNCS & Phase II & 9700 & NA & 22320 & NA & NA & 497000 & 1657 & 446 & NA & 16 & 4330 & 17300 & 97 \\
\hline
\end{tabular}

a THS: top surface and hard shell.

b PCL: porous core layer.

c ET: entire tubercle without layered structure.

d TNCS: thin corrosion scales.

e NA: not analyzed. 


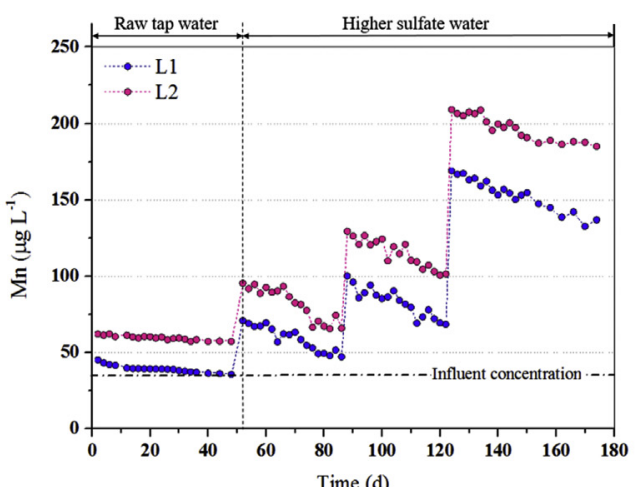

(a)

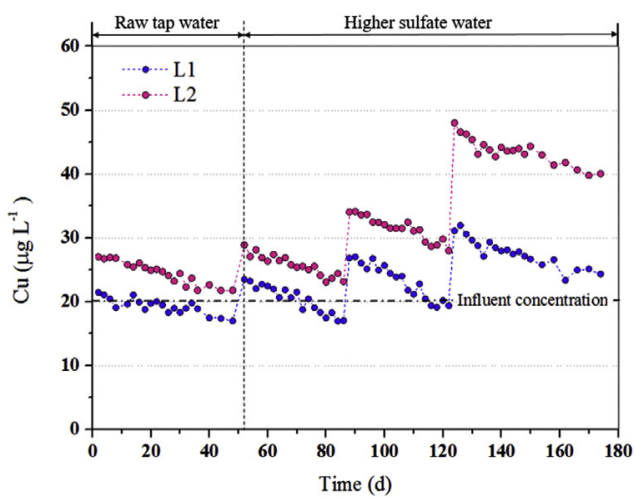

(b)

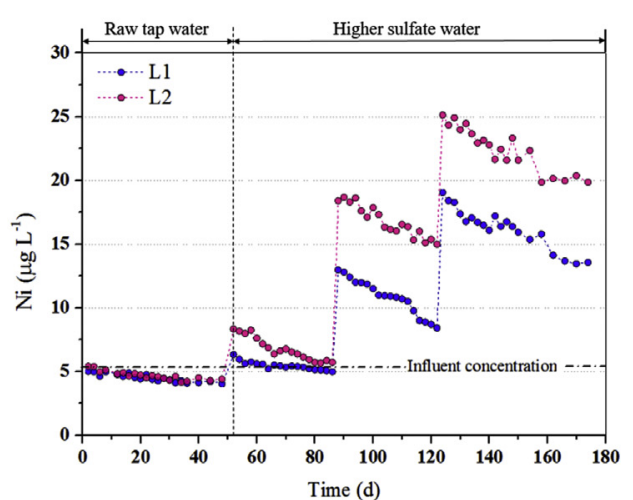

(c)

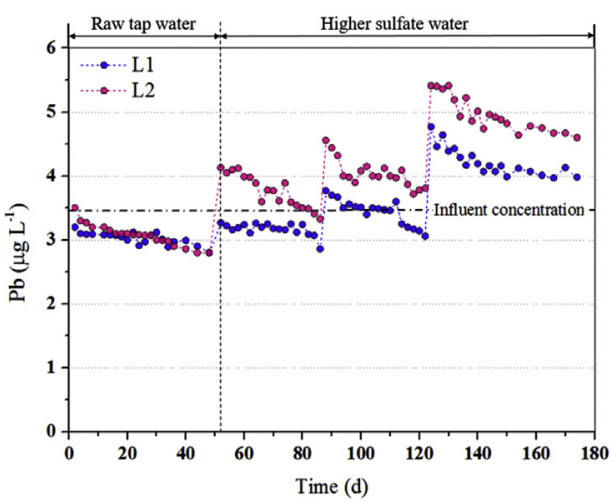

(d)

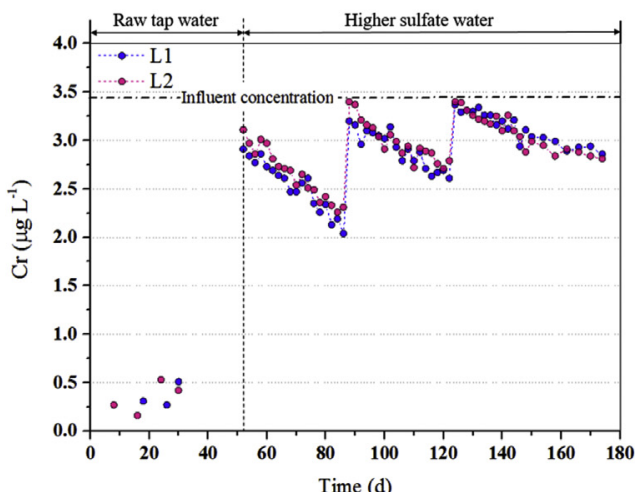

(e)

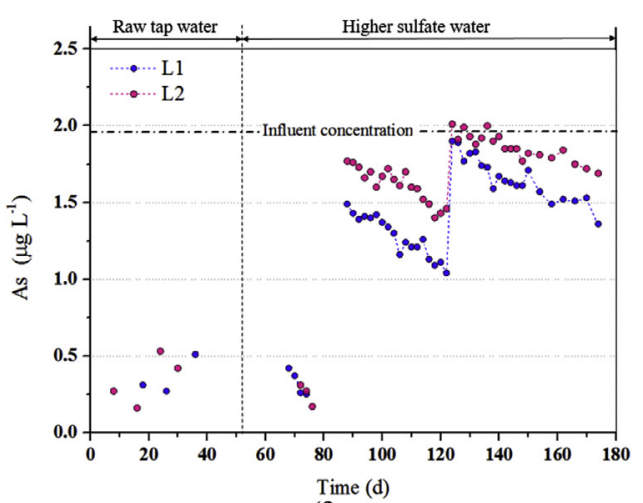

(f)

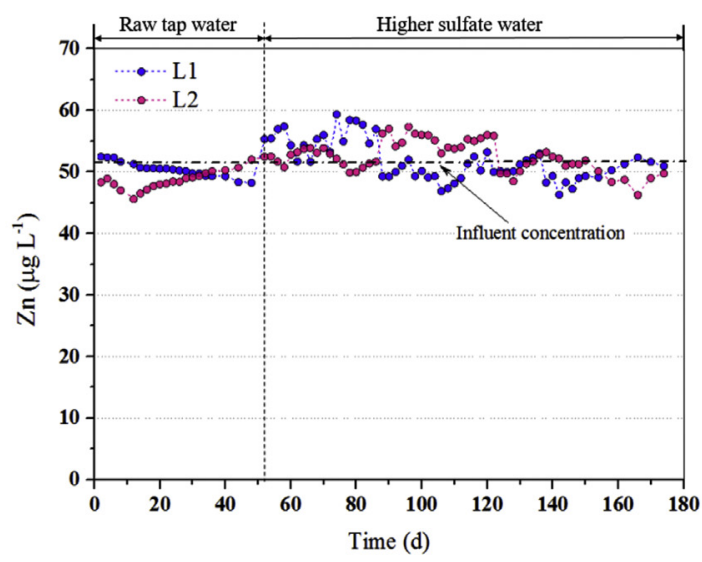

(g)

Fig. 1. Changes of heavy metal release in $\mathrm{L} 1$ and $\mathrm{L} 2$ with time under different sulfate concentrations (a) $\mathrm{Mn}$, (b) $\mathrm{Cu}$, (c) $\mathrm{Ni}$, (d) $\mathrm{Pb}$, (e) $\mathrm{Cr}$, (f) $\mathrm{As}$, (g) $\mathrm{Zn}$. Raw tap water: $2-50 \mathrm{~d}$, $\mathrm{SO} \mathrm{R}_{4}^{2-}$ $75 \mathrm{mg} \mathrm{L}^{-1}$; Higher sulfate water: (1) 52-86 d, SO-4- $200 \mathrm{mg} \mathrm{L}^{-1}$; (2) 88-122 d, SO4 $4^{-}: 250 \mathrm{mg} \mathrm{L}^{-1}$ (L1), $230 \mathrm{mg} \mathrm{L}^{-1}$ (L2); (3) $124-174 \mathrm{~d}^{2}, \mathrm{SO}_{4}^{2-}: 300 \mathrm{mg} \mathrm{L}^{-1}$ (L1), $250 \mathrm{mg} \mathrm{L}^{-1}$ (L2). 
releases of $\mathrm{As}, \mathrm{Cu}, \mathrm{Mn}, \mathrm{Ni}$ and $\mathrm{Pb}$ in $\mathrm{L} 2$ were greater. In pipe section reactors (L3), heavy metal release exhibited similarity to L1 and L2. The mean concentrations of these heavy metals under different sulfate concentrations are show in Table 3. There was no correlation between $\mathrm{Zn}$ release and sulfate concentration in all pipe loops (reactor).

Mn. Mn occurrence in corrosion scales was mainly due to the formation and deposition of Mn oxyhydroxide that originated from the source water (Peng et al., 2010; Swietlik et al., 2011). Under anoxic environments, Mn oxides/oxyhydroxides were prone to reduction and re-solubilization, with associated release of adsorbed substance (e.g. As, Pb, Ni, Cd, Cu, V) (Hill et al., 2010). As shown in Fig. 1, higher sulfate levels can cause higher release of Mn. Further correlation analyses (Fig. S4) indicated that Mn release was positively related to sulfate concentration in all pipe loops $\left(R^{2}\right.$ : $\mathrm{L} 1=0.72 ; \mathrm{L} 2=0.59$ ). The mean effluent concentrations of $\mathrm{Mn}$ in $\mathrm{L} 1$ $\left(154 \mu \mathrm{g} \mathrm{L}^{-1}\right), \mathrm{L} 2\left(115 \mu \mathrm{g} \mathrm{L}^{-1}\right)$ and $\mathrm{L} 3\left(117 \mu \mathrm{g} \mathrm{L}^{-1}\right)$ all exceeded the drinking water standards of China (100 $\mu \mathrm{g} \mathrm{L}^{-1}$, GB 5749-2006), when the sulfate concentration increased to $300 \mathrm{mg} \mathrm{L}^{-1}$, $230 \mathrm{mg} \mathrm{L}^{-1}$ and $300 \mathrm{mg} \mathrm{L}^{-1}$, respectively (Fig. 1, Table 3 ). XRF results demonstrated that the contents of Mn in THS, PCL, ET and TNCS (L2) decreased at higher sulfate water levels, and the decrements were $194,233,258$ and $443 \mu \mathrm{g} \mathrm{L}^{-1}$, respectively (Table 2). The oxygen consumption for L1 and L2 also increased with sulfate, especially for L2 (Fig. S5). For example, the residual DO concentration decreased rapidly from 6.67 to $0.98 \mathrm{mg} \mathrm{L}^{-1}$ in $\mathrm{L} 2$, when the pipe loop operated for $8 \mathrm{~h}$ (an entire operation cycle was $48 \mathrm{~h}$ ), which was much lower than that of $\mathrm{L} 1$ ( $3.65 \mathrm{mg} \mathrm{L}^{-1}$ after $26 \mathrm{~h}$ operation). Therefore, when switching to higher sulfate water, the anaerobic condition might contribute to the release of $\mathrm{Mn}$ in reduced and more soluble form, which needs to be confirmed.

$\mathbf{N i}, \mathbf{C u}$. Similar to $\mathrm{Mn}$ release, elevated levels of $\mathrm{Ni}$ and $\mathrm{Cu}$ were found in all pipe loops when initially increasing sulfate concentration (Fig. 1, Table 3). The concentrations of Ni in L2 $\left(22 \mu \mathrm{g} \mathrm{L}^{-1}\right)$ and $\mathrm{L} 3\left(23 \mu \mathrm{g} \mathrm{L}^{-1}\right)$ also exceeded the drinking water standards (20 $\mu \mathrm{g} \mathrm{L}^{-1}$ ), when the sulfate concentrations increased to $250 \mathrm{mg} \mathrm{L}^{-1}$ (L2) and $400 \mathrm{mg} \mathrm{L}^{-1}$ (L3), respectively. XRF results showed that the contents of $\mathrm{Ni}$ and $\mathrm{Cu}$ both decreased, sometimes to undetectable levels, in most of the scales at phase II (Table 2). A strong positive relationship existed between the release of $\mathrm{Ni}$ and Mn $\left(\mathrm{R}^{2}: \mathrm{L} 1=0.95, \mathrm{~L} 2=0.90\right)$, while relatively weak correlation existed between the release of $\mathrm{Ni}$ and sulfate $\left(R^{2}: \mathrm{L} 1=0.73\right.$, $\mathrm{L} 2=0.65$ ) (Fig. S4). Shi and Taylor (2007) found that $\mathrm{Cu}$ release was controlled by the dissolution of the corrosion scales, not by the corrosion rate of the metal. Mn-containing deposits could absorb $\mathrm{Cu}$ in DWDS, and the destabilization/re-solubilization of $\mathrm{Mn}$ deposits might increase the $\mathrm{Cu}$ ions in consumer taps (Gerke et al., 2016). Cu release was strongly correlated with $M n$ release $\left(R^{2}\right.$ : $\mathrm{L} 1=0.82, \mathrm{~L} 2=0.97)$, but weakly correlated with sulfate $\left(\mathrm{R}^{2}\right.$ : $\mathrm{L} 1=0.53, \mathrm{~L} 2=0.50$ ) (Fig. S4). Mn compounds can also absorb Ni effectively (Trivedi et al., 2001). Hence, it might indicate that the

Table 3

Mean values of heavy metal concentrations of influents and effluents in pipe section reactors (L3) under different sulfate concentrations.

\begin{tabular}{llllllllll}
\hline \multirow{2}{*}{ Pipe loop } & Water type & $\mathrm{SO}_{4}^{2-}\left(\mathrm{mg} \mathrm{L}^{-1}\right)$ & \multicolumn{6}{c}{ Metal concentration $\left(\mu \mathrm{L} \mathrm{L}^{-1}\right)$} \\
\cline { 5 - 9 } & & & $\mathrm{Mn}$ & $\mathrm{Cu}$ & $\mathrm{Zn}$ & $\mathrm{Pb}$ & $\mathrm{Ni}$ & $\mathrm{Cr}$ & $\mathrm{As}$ \\
\hline \multirow{2}{*}{ L3 } & Influents & 75 & 34 & 20 & 50 & 3.4 & 5.3 & 3.4 & 2.0 \\
& Effluents & 75 & 68 & 25 & 48 & 3.1 & 5.2 & 2.7 & 1.3 \\
& 200 & 75 & 26 & 49 & 3.6 & 10.3 & 2.8 & 1.5 \\
& 300 & 117 & 31 & 53 & 3.9 & 16.4 & 2.8 & 1.5 \\
& 400 & 137 & 44 & 51 & 5.0 & 22.8 & 2.9 & 1.6 \\
& 500 & 168 & 55 & 49 & 5.7 & 28.3 & 3.0 & 1.8 \\
& 600 & 180 & 60 & 56 & 7.0 & 34.3 & 3.7 & 2.0 \\
\hline
\end{tabular}

release of $\mathrm{Cu}$ and Ni were mainly accompanied by the release of Mn under higher sulfate condition.

$\boldsymbol{A s}, \boldsymbol{C r}, \boldsymbol{P b}$. Under raw tap water condition, the effluent concentrations of As and $\mathrm{Cr}$ were very low, and often undetectable. At higher sulfate water levels, the release of As and $\mathrm{Cr}$ increased but remained lower than their influent concentrations (Fig. 1, Table 3). As release was positively correlated with $M n$ release $\left(R^{2}: L 1=0.78\right.$, $\mathrm{L} 2=0.75)$, while $\mathrm{Cr}$ release was more associated with sulfate levels $\left(\mathrm{R}^{2}: \mathrm{L} 1=0.86, \mathrm{~L} 2=0.84\right)$ (Fig. S4). Pb release clearly increased with sulfate level. But under raw tap water condition, $\mathrm{Pb}$ release was also lower than its influent concentration. A strong positive correlation existed between the release of $\mathrm{Pb}$ and $\mathrm{Mn}\left(\mathrm{R}^{2}: \mathrm{L} 1=0.94, \mathrm{~L} 2=0.91\right)$, and relative weak relationship existed between $\mathrm{Pb}$ release and sulfate level (Fig. S4). In the presence of high concentrations of sulfate water, the contents of $\mathrm{As}, \mathrm{Cr}$, and $\mathrm{Pb}$ in all analyzed scales decreased (Table 2). The ability for iron oxides to adsorb As is wellknown, and compounds commonly found in iron corrosion scales (such as $\alpha-\mathrm{FeOOH}, \gamma-\mathrm{FeOOH}, \mathrm{Fe}_{3} \mathrm{O}_{4}$ et al.) have similar adsorptive properties, which could therefore concentrate As and potentially release it into the DWDS (Lytle et al., 2004). Mn oxides/oxhydroxides on pipe internal surfaces or iron corrosion scales also can effectively adsorb $\mathrm{Cr}$, $\mathrm{Cu}, \mathrm{Pb}$ et al. (Lytle et al., 2004; Gerke et al., 2016; Manceau et al., 1992). Therefore, we suspect that the adsorption of $\mathrm{As}, \mathrm{Cr}$ and $\mathrm{Pb}$ by $\mathrm{Fe} / \mathrm{Mn}$ based solids within corrosion scales accounts for their relatively lower effluent concentrations. Moreover, Mn oxides could oxidize some adsorbed metal ions, e.g., $\mathrm{Cr}$ (III) to $\mathrm{Cr}(\mathrm{VI})$, changing the toxicity of the heavy metals (Gerke et al., 2016). Cr (IV) bound to Mn oxides/oxhydroxides and ingested is a potential human health risk.

\subsection{Iron release and relationships between iron and heavy metal release}

Curves of total iron release for L1 and L2 exhibited similar variation during the entire experimental period (Fig. 2). The total iron concentrations increased at the initial stage with increasing sulfate concentration, and then decreased with time (in accord with the results observed in $\mathrm{L} 3$, see below). Compared to $\mathrm{L} 1$, total iron release in L2 was greatly affected by sulfate concentration. The concentrations of total iron in $\mathrm{L} 2$ nearly all exceeded $0.3 \mathrm{mg} \mathrm{L}^{-1}$ (upper limit of the drinking water standard for iron in China) when switching to
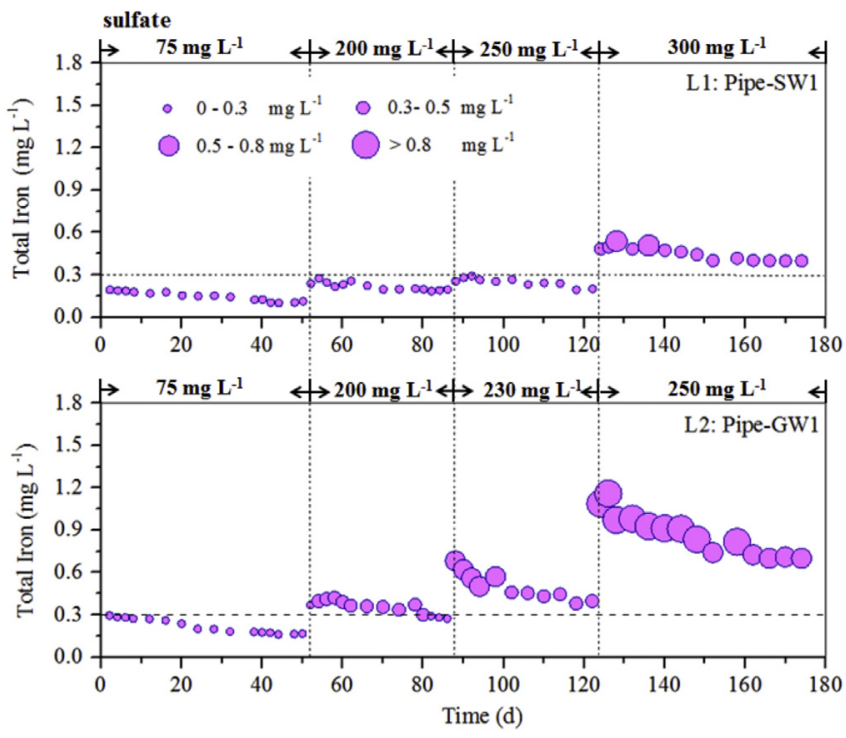

Fig. 2. Total iron release of L1 and L2 under different sulfate concentrations. 
higher sulfate water, and the effluents always exhibited a yellowish color. The total iron release fluctuation scenarios (" $\Delta$ total iron release" = "total iron release sample measurement" minus "average total iron release in corresponding experimental phase") under different sulfate concentrations for L1 and L2 are illustrated in Fig. S6. The " $\Delta$ total iron release" for $\mathrm{L} 2$ changed over a wider range from $-0.057-0.076 \mathrm{mg} \mathrm{L}^{-1}$ (phase I) to $-0.078-0.069 \mathrm{mg} \mathrm{L}^{-1}$, $-0.120-0.182 \mathrm{mg} \mathrm{L}^{-1}$ and $-0.170-0.290 \mathrm{mg} \mathrm{L}^{-1}$, when the sulfate concentration increased to 200,230 and $250 \mathrm{mg} \mathrm{L}^{-1}$, respectively. However, the " $\Delta$ total iron release" for L1 had a narrower range of between $-0.053-0.090 \mathrm{mg} \mathrm{L}^{-1}$ during the entire experimental phases. The total iron release fluctuation scenarios under various operation conditions can reflect pipe scale stability (Yang et al., 2014). These results demonstrated that the corrosion scales of GW pipes were more affected by sulfate and the corrosion scale stability of SW pipes was higher than that of GW pipes, since the same water matrix (lab tap water) was used in this study and the change in water quality was only the level of sulfate.

Sulfate is often the causative agent of red water, and this is reflected in indices such as the Larson index (Li et al., 2010). Sulfate can increase ferrous iron diffusion from pipe surfaces into bulk water, resulting in increased iron concentrations, but the pathways involved are not well understood. In the present study, we found that increasing sulfate concentration leads to a relatively anaerobic environment in distribution systems (especially for GW pipes). For L2, the DO concentration decreased rapidly from 6.67 to $0.98 \mathrm{mg} \mathrm{L}^{-1}$ when the sulfate concentration increased to $250 \mathrm{mg} \mathrm{L}^{-1}$. However, the concentration of DO in L1 decreased slowly from 6.67 to $3.65 \mathrm{mg} \mathrm{L}^{-1}$, even when the sulfate concentration increased to $300 \mathrm{mg} \mathrm{L}^{-1}$. According to the Kuch mechanism, it is possible for previously deposited ferric scales to act as an electron acceptor and produce ferrous iron to diffuse into water in the absence of oxygen (Eqn. (1)) (Kuch, 1988). Sarin et al. also reported that decreasing the oxidant concentrations, such as DO, in water can increase the amount of iron release from corroded iron pipes (Sarin et al., 2004). Therefore, the anaerobic condition caused by increased sulfate concentrations could be an important factor increasing total iron release.

$\mathrm{Fe}_{(\text {metal })}+2 \mathrm{FeOOH}_{(\text {scale })}+2 \mathrm{H}^{+} \rightarrow 3 \mathrm{Fe}^{2+}+4 \mathrm{OH}^{-}$

Total iron release for L3 was similar to L1 and L2 when sulfate concentration increased (Fig. 3). Under a fixed sulfate concentration, total iron release in ran 1 was greater than that in ran 2, and

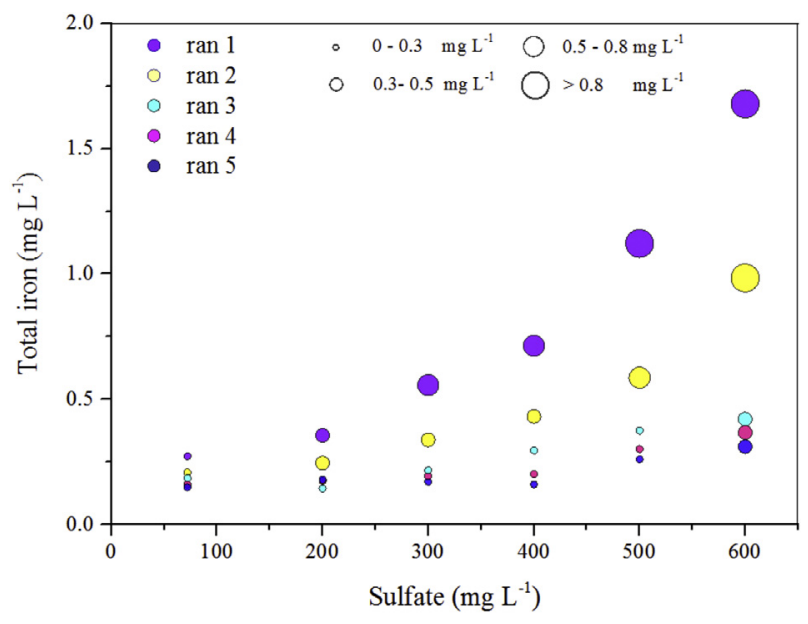

Fig. 3. Total iron release of L3 under different sulfate concentrations. ran 2 was greater than ran 3 . The total iron concentrations in ran 3 , ran 4 , and ran 5 were closer. The reason for this might be the contents of iron oxides, which can be easily released into the water, decreased over time. Sulfate could cause a more protective scale on the pipe surface, or change the corrosion scales from less stable to more stable constituents (Yang et al., 2014; Imran et al., 2006; McNeill and Edwards, 2001). In the present study, the contents of stable iron components, such as $\alpha-\mathrm{FeOOH}$ and $\mathrm{Fe}_{3} \mathrm{O}_{4}$ all increased over time in the presence of higher sulfate water concentration, and this also could account for the gradual lowering of iron release. The following section provides corrosion scale comparison and discussion.

The total iron release was positively correlated with sulfate both in $\mathrm{L} 1\left(\mathrm{R}^{2}=0.70\right)$ and $\mathrm{L} 2\left(\mathrm{R}^{2}=0.58\right)$ (Fig. 4). Strong positive correlations also existed between the release of Fe \& Mn, Fe \& Ni, Fe \& $\mathrm{Cu}$, and $\mathrm{Fe} \& \mathrm{~Pb}$, with $\mathrm{R}^{2}$ all being greater than 0.8 . Compared to other heavy metals, $\mathrm{Cr}$ release was more closely related to sulfate level $\left(R^{2}: L 1=0.86, L 2=0.84\right)$ and As release was correlated to Mn release $\left(R^{2}: L 1=0.78, L 2=0.75\right)$. This suggests that total iron release triggered by sulfate could result in pre-accumulated/ adsorbed heavy metal release back into the drinking water. Therefore, the total iron release not only contributed to discolored water, but was also a health concern with concomitant heavy metal release into DWDS.

\subsection{Effect of corrosion scale composition transformation on heavy metal release}

Corrosion scales with different morphologies were collected from newly obtained pipe sections in L1 - L3 under different experimental phases, and the crystalline phases were characterized by XRD (Fig. 5). For the initial corrosion scale samples (from pipe sections in phase I), $\alpha$-FeOOH and $\mathrm{Fe}_{3} \mathrm{O}_{4}$ were the main constituents of THS and ET. Relatively higher content of unstable iron components, such as $\gamma-\mathrm{FeOOH}$, siderite $\left(\mathrm{FeCO}_{3}\right)$, green rust $\left(\mathrm{Fe}_{6}(\mathrm{OH})_{12} \mathrm{CO}_{3}\right.$, GR) and amorphous iron oxides existed in PCL. For the two scales of TNCS, amorphous iron oxides were in greatest abundance, but the contents of $\alpha$-FeOOH were relatively lower compared with THS and ET.

After moving to a higher sulfate water concentration, some notable characteristics of the transformation of scale crystalline composition were observed. First, the relatively abundance of $\mathrm{Fe}_{3} \mathrm{O}_{4}$ in all kinds of corrosion scales increased when at higher sulfate levels and the increased percentages were all $>10 \%$ except PCL (6\%). The relative contents of $\alpha-\mathrm{FeOOH}$ increased in all samples by $2 \%-$ $4 \%$. Sulfate was deemed to increase iron corrosion, and accelerate the formation of ferrous iron from elemental iron (Eqn. (2)). Ferrous iron can be oxidized by $\mathrm{DO}$ to form $\alpha$-FeOOH and $\mathrm{Fe}_{3} \mathrm{O}_{4}$ under low oxidation rates (Eqn. (3)-(5)), according to the Siderite model proposed by Sontheimer et al. (1981).

$$
\begin{aligned}
& \mathrm{Fe}(\mathrm{s}) \rightarrow \mathrm{Fe}^{2+}+2 \mathrm{e}^{-} \\
& 2 \mathrm{Fe}^{2+}+1 / 2 \mathrm{O}_{2}+4 \mathrm{OH}^{-} \rightarrow 2 \alpha-\mathrm{FeOOH}+\mathrm{H}_{2} \mathrm{O} \\
& 2 \mathrm{FeCO}_{3}+1 / 2 \mathrm{O}_{2}+4 \mathrm{OH}^{-} \rightarrow 2 \alpha-\mathrm{FeOOH}+\mathrm{CO}_{2} \\
& 2 \mathrm{FeCO}_{3}+1 / 2 \mathrm{O}_{2} \rightarrow \mathrm{Fe}_{3} \mathrm{O}_{4}+\mathrm{CO}_{2}
\end{aligned}
$$

Equations (3)-(5) are oxidation reactions, which could promote the formation of $\alpha-\mathrm{FeOOH}$ and $\mathrm{Fe}_{3} \mathrm{O}_{4}$ by consuming $\mathrm{DO}$, and lead to an anaerobic environment in DWDS. Several studies have reported that ferric hydroxides (e.g., $\alpha$-FeOOH, $\beta$-FeOOH, $\gamma$-FeOOH and amorphous ferric oxyhydroxides) can be converted to $\mathrm{Fe}_{3} \mathrm{O}_{4}$ by iron reducing bacterial (IRB) under anaerobic condition (Lovley, 1998; 


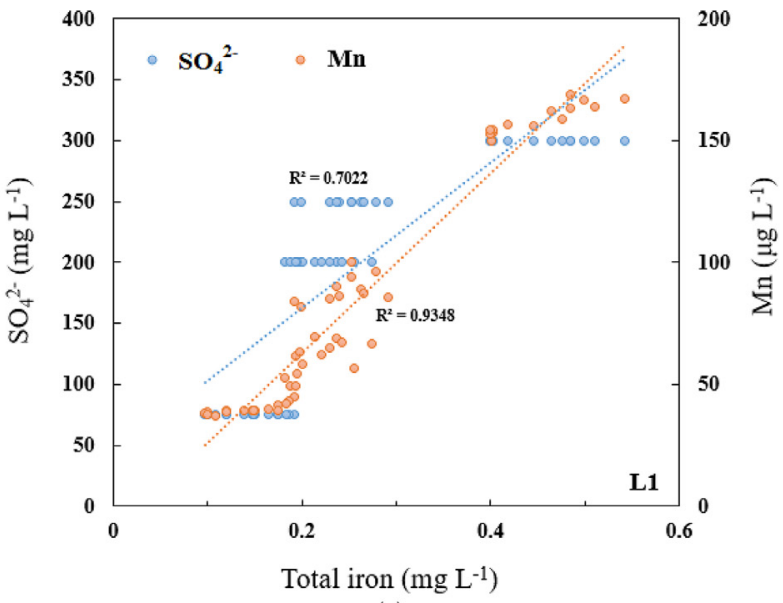

(a)

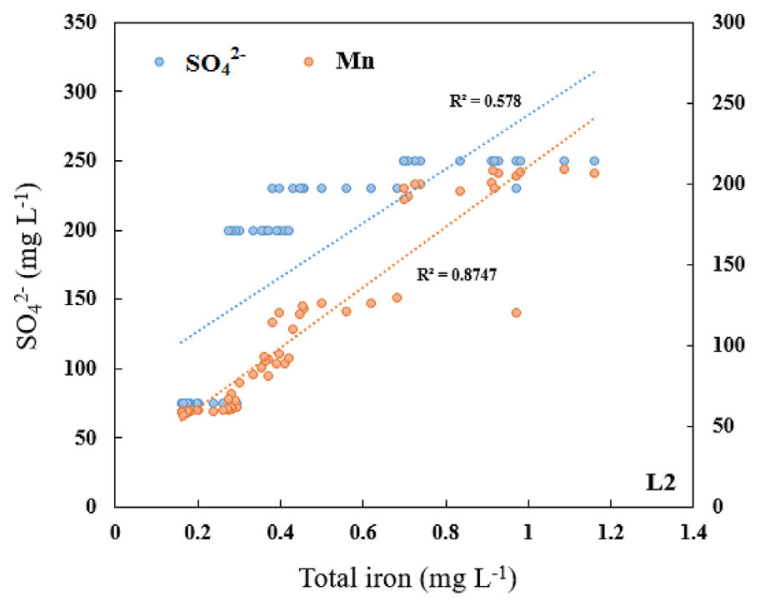

(b)

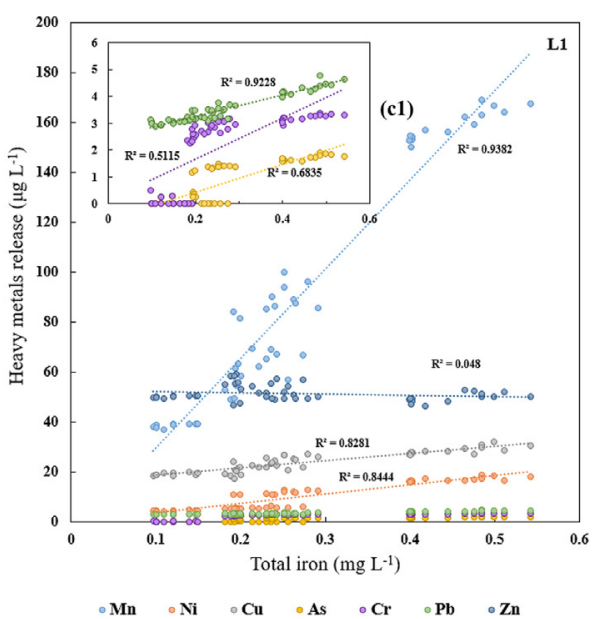

(c)

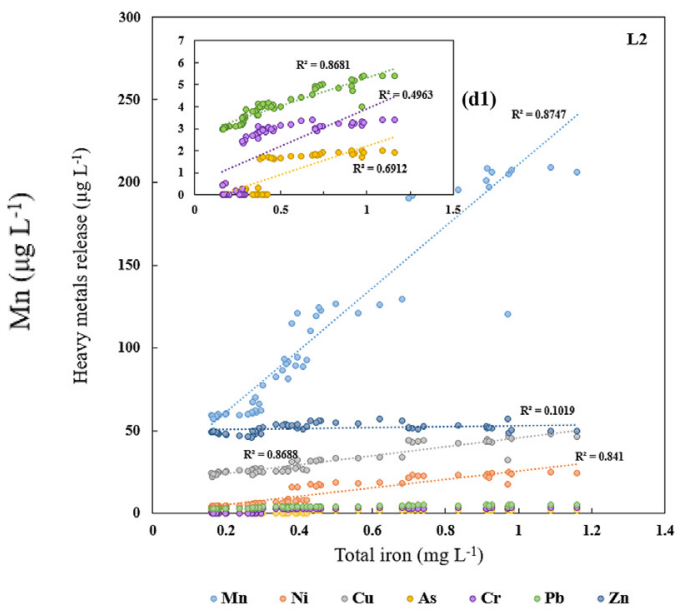

(d)

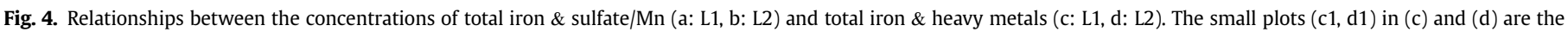
enlarged views of the relationships between the concentrations of $\mathrm{Fe} \& \mathrm{As}$, Fe \& $\mathrm{Cr}$ and $\mathrm{Fe} \& \mathrm{~Pb}$.

Roh et al., 2003; Sun et al., 2014b). In the present study, the bacterial communities in scale samples were analyzed by $16 \mathrm{~S}$ rRNA pyrosequencing (Supplementary materials A). Results showed that the relative abundances of IRB in all corrosion scales also increased when switching to higher sulfate water (Fig. S7, Table S3). The high abundance of IRB in scales could favor the formation and preservation of $\mathrm{Fe}_{3} \mathrm{O}_{4} \cdot \mathrm{Fe}_{3} \mathrm{O}_{4}$ is thermodynamically stable, which could produce a dense and compact corrosion scale. Corrosion scales with high $\mathrm{Fe}_{3} \mathrm{O}_{4}$ content usually possesses protective and anti-corrosive properties, which serve as barriers hindering the diffusion of corrosive ions into corrosion scales (Sarin et al., 2001, 2004; Lytle et al., 2005). $\mathrm{Fe}_{3} \mathrm{O}_{4}$ is also an effective sorbent for some heavy metals such as $\mathrm{Cu}, \mathrm{Pb}, \mathrm{Cr}$, As (Rajput et al., 2016; Yantasee et al., 2007; Hu et al., 2004). Therefore, $\mathrm{Fe}_{3} \mathrm{O}_{4}$ could act as a barrier to hinder the release of heavy metals on the one hand, and also to act as a sink to adsorb released heavy metals. The formation of $\mathrm{Fe}_{3} \mathrm{O}_{4}$ might be one of the most important factors for inhibiting the release of total iron and heavy metals.

Second, the percentages of some unstable ferric or ferrous iron oxides (including $\beta$-FeOOH, $\gamma$ - $\mathrm{FeOOH}$ and $\mathrm{FeCO}_{3}$ and amorphous iron oxides) in THS, ET, and two samples of TNCS all decreased when switching to higher sulfate water. The decreased percentages were all $>10 \%$. $\beta$ - $\mathrm{FeOOH}, \gamma-\mathrm{FeOOH}, \mathrm{FeCO}_{3}$ and amorphous iron oxides were chemically unstable, and the relatively higher percentage of these in corrosion scales indicated the weak tolerance of distribution pipes to feed water chemistry changes (Yang et al., 2014). Therefore, the decrease of these unstable ferric or ferrous iron oxides means that the iron corrosion scales in pipe loops tend to be more stable, which could also account for the decreased release of heavy metals over time.

Third, we found that when switching to higher sulfate water, the relative abundance of GR in THS decreased from $15 \%$ to $8 \%$, while the contents of GR in the two samples of TNCS both increased (L2: from $16 \%$ to $26 \%$, L3: from $16 \%$ to $28 \%$ ). GR was chemically unstable, and could be oxidized by dissolved oxygen into $\mathrm{Fe}_{3} \mathrm{O}_{4}, \alpha$-FeOOH, $\gamma$ $\mathrm{FeOOH}$ and $\gamma-\mathrm{Fe}_{2} \mathrm{O}_{3}$, depending on $\mathrm{pH}$ and oxidation rate (Pineau et al., 2008). Under anaerobic condition (as in L2 at phase II), GR can remain for a long time (Refait et al., 3003). The higher abundance of these unstable ferrous oxides could lead to more serious heavy metal release in DWDS. This might explain why the release of total iron and some heavy metals were more serious in $\mathrm{L} 2$ than those in L1. GR and sulfate reducing bacterial (SRB) always coexisted, due to the presence of GR, and this could favor the colonization of SRB (Refait et al., 2003). Bacterial community analyses showed that the relatively abundance of SRB in all corrosion scales increased under higher sulfate concentration, especially in the two samples of TNCS (Fig. S7, Table S3). SRB were usually associated with anaerobic iron corrosion, which could favor sulfide production 


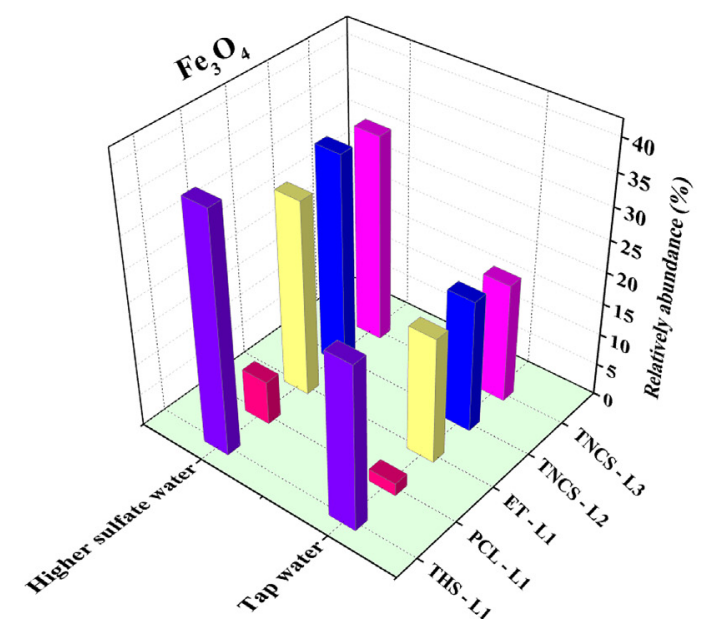

(a)

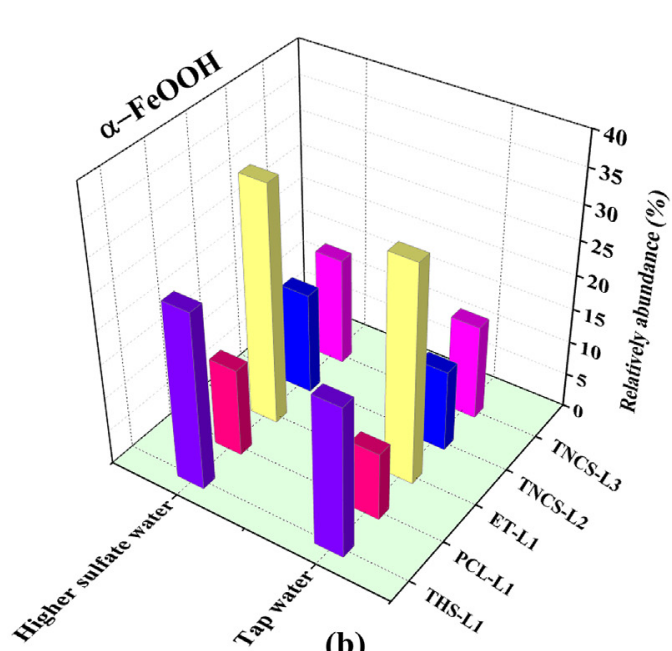

(b)

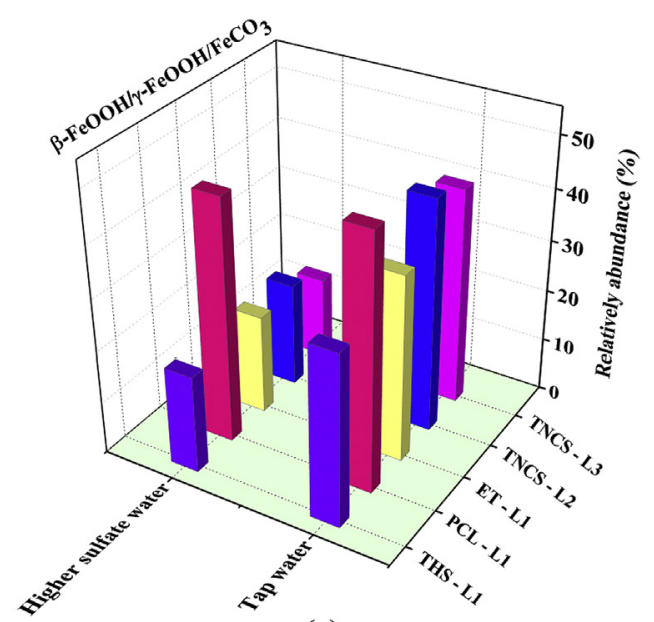

(c)

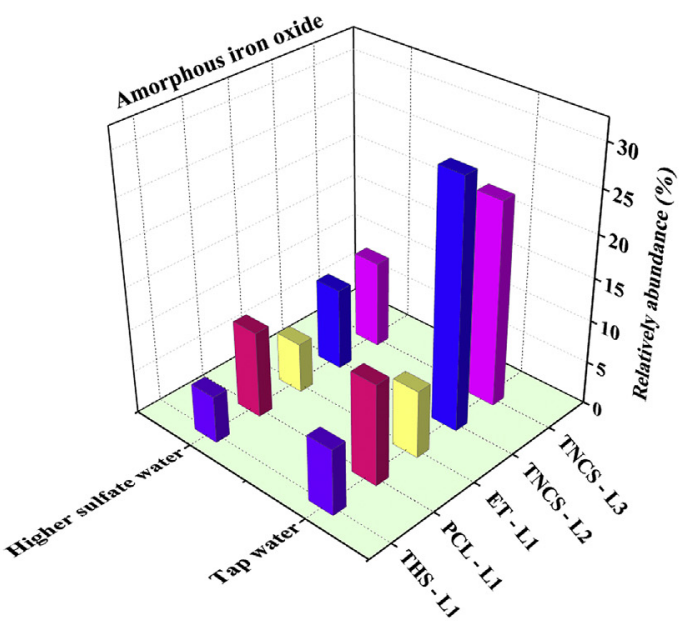

(d)

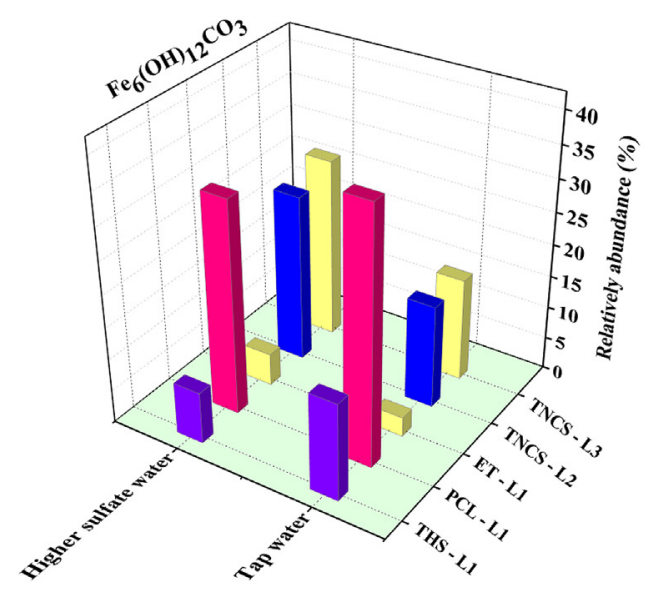

(e)

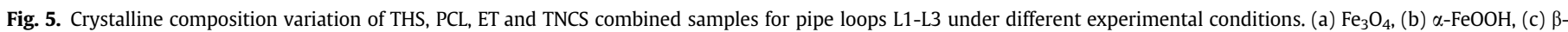
$\mathrm{FeOOH} / \gamma-\mathrm{FeOOH} / \mathrm{FeCO}_{3}$, (d) Amorphous iron oxide, (e) $\mathrm{Fe}_{6}(\mathrm{OH})_{12} \mathrm{CO}_{3}$.

and thus promote iron corrosion and ferrous iron formation (Lytle et al., 2005; Pineau et al., 2008). However, SRB could use sulfate as an electron acceptor and generate sulfide $\left(\mathrm{S}^{2-}\right)$ in an anaerobic environment, the biogenically produced $S^{2-}$ could react with 
dissolved metals to form metal sulfide precipitates, such as $\mathrm{Cu}, \mathrm{Zn}$, $\mathrm{Ni}, \mathrm{Fe}, \mathrm{Al}, \mathrm{As}$ and Mn (Jong and Parry, 2003). Therefore, the growth of SRB could also decrease heavy metal release.

\section{Conclusions}

Changes in water chemistry can result in accumulated/adsorbed trace heavy metals in iron corrosion scales being released back into domestic water supplies thus leading to reduced water quality. The present work systematically investigated the effect of sulfate on the release of trace heavy metals from iron corrosion scales to bulk water.

The release of $\mathrm{Mn}, \mathrm{Ni}, \mathrm{Cu}, \mathrm{Pb}, \mathrm{Cr}$ and $\mathrm{As}$ from iron corrosion scales increased immediately after sulfate concentration increased and then gradually decreased over time. Pipes historically transporting GW had greater heavy metal release, compared with pipes historically transporting SW. Significant correlations $\left(R^{2}>0.8\right)$ existed between the release of $\mathrm{Fe} \& \mathrm{Mn}, \mathrm{Fe} \& \mathrm{Ni}, \mathrm{Fe} \& \mathrm{Cu}$, and $\mathrm{Fe} \&$ $\mathrm{Pb}$ in all pipe loops. Mn release was also associated with other metals, and positive correlations existed between $\mathrm{Mn} \& \mathrm{Ni}\left(\mathrm{R}^{2}\right.$ : $\mathrm{L} 1=0.95, \mathrm{~L} 2=0.90), \mathrm{Mn} \& \mathrm{~Pb}\left(\mathrm{R}^{2}: \mathrm{L} 1=0.94, \mathrm{~L} 2=0.91\right), \mathrm{Mn} \& \mathrm{Cu}$ $\left(\mathrm{R}^{2}: \mathrm{L} 1=0.82, \mathrm{~L} 2=0.97\right)$ and $\mathrm{Mn} \& \mathrm{As}\left(\mathrm{R}^{2}: \mathrm{L} 1=0.79, \mathrm{~L} 2=0.75\right)$.

For the pipes historically transporting SW, corrosion scales tended to be more stable in the presence of higher sulfate levels, with a larger proportion of stable constituents (mainly $\mathrm{Fe}_{3} \mathrm{O}_{4}$ ) and fewer unstable compounds $\left(\beta-\mathrm{FeOOH}, \gamma-\mathrm{FeOOH}, \mathrm{FeCO}_{3}\right.$ and amorphous iron oxides). The main functional bacterial communities IRB were favorable for the formation of $\mathrm{Fe}_{3} \mathrm{O}_{4}$. For pipes historically transporting GW, constituents of corrosion scales also achieved more stability, while the anaerobic condition promoted the formation of GR, a main precursor of stable iron constituents. The higher metal release in pipes transporting GW can be partially attributed to the higher GR content. The relative abundance of SRB increased with sulfate concentration in all kinds of scales. The transformation of corrosion scales to a more stable state and the growth of SRB may explain the gradual decrease of heavy metal release over time.

\section{Acknowledgments}

This work was supported by the National Natural Science Foundation of China (51378493) and the National Water Pollution Control and Treatment Special Key Project of China (2012ZX07404002).

\section{Appendix A. Supplementary data}

Supplementary data related to this article can be found at http:// dx.doi.org/10.1016/j.watres.2017.02.021.

\section{References}

Benjamin, M.M., Sontheimer, H., Leroy, P., 1996. Corrosion of Iron and Steel. In Internal Corrosion of Water Distribution Systems. Cooperative Research Report. AWWA Research Foundation, Denver, CO, pp. 29-70.

Fisher, E.L., Fuortes, LJ., Valentine, R.L., Mehrhoff, M., Field, R.W., 2000. Dissolution of 226 Radium from pipe-scale deposits in a public water supply. Environ. Int $26(1-2), 69-73$

Gerke, T.L., Little, B.J., Maynard, J.B., 2016. Manganese deposition in drinking water distribution systems. Sci. Total Environ. 541 (110), 184-193.

Ginige, M.P., Wylie, J., Plumb, J., 2011. Influence of biofilms on iron and manganese deposition in drinking water distribution systems. Biofouling 27 (2), 151-163.

Hill, A.S., Friedman, M.J., Reiber, S.H., Korshin, G.V., Valentine, R.L., 2010. Behavior of trace inorganic contaminants in drinking water distribution systems. J. Am. Water Works Assoc. 102 (7), 107-118.

Hu, J., Lo, I.M.C., Chen, G., 2004. Removal of Cr(VI) by magnetite. Water Sci. Technol. 50 (12), 129-146.

Imran, S.A., Dietz, J.D., Mutoti, G., Xiao, W.Z., Taylor, J.S., Desai, V., 2006. Optimizing source water blends for corrosion and residual control in distribution systems.
J. Am. Water Works Assoc. 98 (5), 107-115.

Jong, T., Parry, D.L., 2003. Removal of sulfate and heavy metals by sulfate reducing bacteria in short-term bench scale upflow anaerobic packed bed reactor runs. Water Res. 37 (14), 3379-3389.

Kuch, A., 1988. Investigations of the reduction and reoxidation kinetics of iron (III) oxide scales formed in waters. Corros. Sci. 28 (3), 221-231.

Larson, T.E., Skold, R.V., 1958. Laboratory studies relating mineral quality of water to corrosion of steel and cast iron. J. Am. Water Works Assoc. 14 (6), 285-288.

Li, D., Li, Z., Yu, J., Cao, N., Liu, R., Yang, M., 2010. Characterization of bacterial community structure in a drinking water distribution system during an occurrence of red water. Appl. Environ. Microbiol. 76 (21), 7171-7180.

Lovley, D.R., 1998. Geomicrobiology: interactions between microbes and minerals. Science 280 (5360), 54-55.

Lytle, D.A., Gerke, T.L., Maynard, J.B., 2005. Effect of bacterial sulfate reduction on iron-corrosion scales. J. Am. Water Works Assoc. 97 (10), 109-120.

Lytle, D.A., Sorg, T.J., Frietch, C., 2004. Accumulation of arsenic in drinking water distribution systems. Environ. Sci. Technol. 38 (20), 5365-5372.

Lytle, D.A., Sorg, T.J., Muhlen, C., Wang, L.L., 2010. Particulate arsenic release in a drinking water distribution system. J. Am. Water Works Assoc. 102 (3), 87-98.

Manceau, A. Charlet, L., Boisset, M.C., Didier, B., Spadini, L., 1992. Clays and Hydrosilicate Gels in Nuclear Fields Sorption and speciation of heavy metals on hydrous Fe and Mn oxides. From microscopic to macroscopic. Appl. Clay Sci. 7 (1), 201-223.

Masters, S., Welter, G.J., Edwards, M., 2016. Seasonal variations in lead release to potable water. Environ. Sci. Technol. 50 (10), 5269-5277.

McNeill, L.S., Edwards, M., 2001. Iron pipe corrosion in distribution systems. J. Am. Water Works Assoc. 93 (7), 88-100.

Peng, C.Y., Hill, A.S., Friedman, M.J., Valentine, R.L., Larson, G.S., Romero, A.M.Y., Reiber, S.H., Korshin, G.V., 2012. Occurrence of trace inorganic contaminants in drinking water distribution systems. J. Am. Water Works Assoc. 104 (3), 53-54.

Peng, C.-Y., Korshin, G.V., Valentine, R.L., Hill, A.S., Friedman, M.J., Reiber, S.H., 2010. Characterization of elemental and structural composition of corrosion scales and deposits formed in drinking water distribution systems. Water Res. 44 (15), 4570-4580.

Pineau, S., Sabot, R., Quillet, L., Jeannin, M., Caplat, C., Dupont-Morral, I., Refait, P., 2008. Formation of the Fe(II-III) hydroxysulphate green rust during marine corrosion of steel associated to molecular detection of dissimilatory sulphitereductase. Corros. Sci. 50 (4), 1099-1111.

Rajput, S., Pittman, C.U., Mohan, D., 2016. Magnetic magnetite $\left(\mathrm{Fe}_{3} \mathrm{O}_{4}\right)$ nanoparticle synthesis and applications for lead $\left(\mathrm{Pb}^{2+}\right)$ and chromium $\left(\mathrm{Cr}^{6+}\right)$ removal from water. J. Colloid Interface Sci. 468, 334-346.

Refait, P., Memet, J.B., Bon, C., Sabot, R., Génin, J.M.R., 2003. Formation of Fe (II) - Fe (III) hydroxysulphate green rust during marine corrosion of steel. Corros. Sci. 45 (4), 833-845.

Reiber, S., Dostal, G., 2000. Well water disinfection sparks surprises. Opflow 26 (3), $1,4-6,14$

Roh, Y., Zhang, C.L., Vali, H., Lauf, R.J., Zhou, J., Phelps, T.J., 2003. Biogeochemical and environmental factors in Fe biomineralization: magnetite and siderite formation. Clays Clay Minerals 51 (1), 83-95.

Schock, M.R., Hyland, R.N., Welch, M.M., 2008. Occurrence of contaminant accumulation in lead pipe scales from domestic drinking-water distribution systems. Environ. Sci. Technol. 42 (12), 4285-4291.

Sarin, P., Snoeyink, V.L., Bebee, J., Jim, K.K., Beckett, M.A., Kriven, W.M., Clement, J.A., 2004. Iron release from corroded iron pipes in drinking water distribution systems: effect of dissolved oxygen. Water Res. 38 (5), 1259-1269.

Sarin, P., Snoeyink, V.L., Bebee, J., Kriven, W.M., Clement, J.A., 2001. Physico-chemical characteristics of corrosion scales in old iron pipes. Water Res. 35 (12), 2961-2969.

Shi, B.Y., Taylor, J.S., 2007. Iron and copper release in drinking-water distribution systems. J. Environ. Health 70 (2), 29-36.

Sontheimer, H., Kolle, W., Snoeyink, V.L., 1981. The siderite model of the formation of corrosion-resistant scales. J. Am. Water Works Assoc. 73 (11), 572-579.

Sun, H., Shi, B., Bai, Y., Wang, D., 2014a. Bacterial community of biofilms developed under different water supply conditions in a distribution system. Sci. Total Environ. 472 (1), 99-107.

Sun, H., Shi, B., Lytle, D.A., Bai, Y., Wang, D., 2014b. Formation and release behavior of iron corrosion products under the influence of bacterial communities in a simulated water distribution system. Environmental science. Process. Impacts 16 (3), 576-585.

Swietlik, J., Raczyk-Stanislawiak, U., Laskowski, T., Nawrocki, J., 2011. Model investigations into the migration of some elements from cast iron and steel into water due to pipe corrosion. Ochr. Środowiska 33 (3), 71-76.

Trivedi, P., Axe, L., Tyson, T.A., 2001. XAS studies of Ni and Zn sorbed to hydrous manganese oxide. Environ. Sci. Technol. 35 (22), 4515-4521.

Yang, F., Shi, B., Bai, Y., Sun, H., Lytle, D.A., Wang, D., 2014. Effect of sulfate on the transformation of corrosion scale composition and bacterial community in cast iron water distribution pipes. Water Res. 59 (4), 46-57.

Yang, F., Shi, B., Gu, J., Wang, D., Yang, M., 2012. Morphological and physicochemical characteristics of iron corrosion scales formed under different water source histories in a drinking water distribution system. Water Res. 46 (16), $5423-5433$

Yantasee, W., Warner, C.L., Sangvanich, T., Addleman, R.S., Carter, T.G., Wiacek, R.J., Fryxell, G.F., Timchalk, C., Warner, M.G., 2007. Removal of heavy metals from aqueous systems with thiol functionalized superparamagnetic nanoparticles. Environ. Sci. Technol. 42 (14), 5114-5119. 